\title{
Study of Serum Homocysteine Level Variations in Sickle Cell Disease: A Meta-analysis Study
}

\author{
Chandrakant G Kamble ${ }^{1}$, Prashant J Hisalkar², Shekhar B Padhyegurjar ${ }^{3}$, Jagdish D Powar ${ }^{4}$, Bhausaheb V Jagdale ${ }^{5}$
}

\begin{abstract}
Background: Serum homocysteine levels have been observed to be increased in sickle cell disease (SCD). The biological mechanism of synthesis and regulation of the homocysteine remains unclear. This meta-analysis aims to provide an overview of the serum homocysteine level changes and to discuss its significance in SCD.

Materials and methods: This meta-analysis is to determine serum homocysteine level changes during SCD and was conducted under the PRISMA guidelines. Without language restrictions, the articles were identified through BioMed, Embase, Pub Med ${ }^{\circledast}$ (U.S. National Library of Medicine, USA), and www.Blood Journal.org, PLoS ONE, Web of Science, LILACS (Latin American and Caribbean Health Sciences Literature), ISI Web of Science, Chemical abstract services-(CAS), Europe PMC, Bio sis Previews, Elsevier Properties S.A., USA. The studies have been considered which were published before March 31, 2018.

Results: Thirty comparative studies were identified out of 8,630 articles and included in the meta-analysis. From the final selected articles, the mean, standard deviation, sample size of cases vs controls were showing compared and calculated by the SPSS latest software version-24. From 30, 18 articles were statistically highly significant, and the remaining 12 articles were statistically not significant. The $p<0.05$ was considered to be statistically significant. The combined estimation of the meta-analysis study is highly significant, since $p<0.000000$, calculated " $t$ " is 25.07 , and degree of freedom is 2,829 .

Conclusion: The study concludes that there is an extremely significant difference between mean serum homocysteine levels in cases and healthy controls. So, the serum homocysteine level can be used as a clinical biomarker for the diagnosis of SCD.

Keywords: Meta-analysis, Serum homocysteine level, Sickle cell disease.

Indian Journal of Medical Biochemistry (2020): 10.5005/jp-journals-10054-0166
\end{abstract}

\section{INTRODUCTION}

Sickle cell disease (SCD) is a widespread genetic disorder characterized by sickle-shaped red blood cells (RBCs) deformity to abnormal rigid and sickle-shaped forms of cells that result in chronic hemolytic disease/anemia, an infective crisis with frequent infections and risks of serious complications. It occurs in high frequency in many tropical countries. ${ }^{1,2}$ Sickle cell disease/SCA patients suffer from various complications such as severe bone pain, hand-foot syndrome, hyperhemolytic crisis, stroke, acute chest pain, femoral head necrosis autosplenectomy, hepatomegaly, priapism, renal failure, heart failure, and leg ulcers. ${ }^{3}$

Homocysteine (tHcy) is a sulfur-containing amino acid, found at low concentration in blood and cells. It is an important intermediate molecule involved in the biosynthesis of methionine and cysteine. The high plasma concentration of tHcy is a well-established risk factor for several disorders, including cardiovascular disease stroke, venous thrombosis, and arteriosclerosis. ${ }^{4}$

It (tHcy) is an important vascular risk factor, which may contribute to the ischemic phenomenon of SCD has attracted some interest in plasma total homocysteine ( $\mathrm{tHcy}$ ) levels in patients with SCD. However, almost all the studies in SCD have been in children, who presumably have a less predisposition to hyperhomocysteinemia than adults. ${ }^{5}$

Homocysteine may contribute to the ischemic phenomena present in $\mathrm{HbSS}$ has attracted some interest in plasma total tHcy. In a previous study, it was shown that the plasma concentration of tHcy among HbSS subjects was approximately 1.5-fold higher than that of healthy controls. Additionally, SCD patients have higher plasma tHcy concentration despite elevated plasma folate
${ }^{1}$ Department of Biochemistry, People's Medical College Hospital, Bhopal, Madhya Pradesh, India

${ }^{2}$ Department of Biochemistry, Government Medical College and Hospital, Dungarpur, Rajasthan, India

${ }^{3,4}$ Department of PSM, SMBT Institute of Medical Sciences and Research Centre, Nashik, Maharashtra, India

${ }^{5}$ Department of Physiology, SMBT Institute of Medical Sciences and Research Centre, Nashik, Maharashtra, India

Corresponding Author: Prashant J Hisalkar, Department of Biochemistry, Government Medical College and Hospital, Dungarpur, Rajasthan, India, Phone: +91 9422610220, e-mail: pjhisalkar@yahoo. co.in

How to cite this article: Kamble CG, Hisalkar PJ, Padhyegurjar SB, et al. Study of Serum Homocysteine Level Variations in Sickle Cell Disease: A Meta-analysis Study. Indian J Med Biochem 2020;24(3):104-114.

Source of support: Nil

Conflict of interest: None

levels and vitamin $\mathrm{B}_{12}$ concentration similar to those observed in controls. $^{6}$

Elevations of plasma homocysteine levels are a risk factor for endothelial cell damage and thrombosis, which are implicated in SCD-related vaso-occusion. ${ }^{\text {? }}$

\section{Materials and Methods}

\section{Literature Search Strategy}

Meta-analysis was done by searching of published studies which are reporting the "serum homocysteine level variations in sickle 


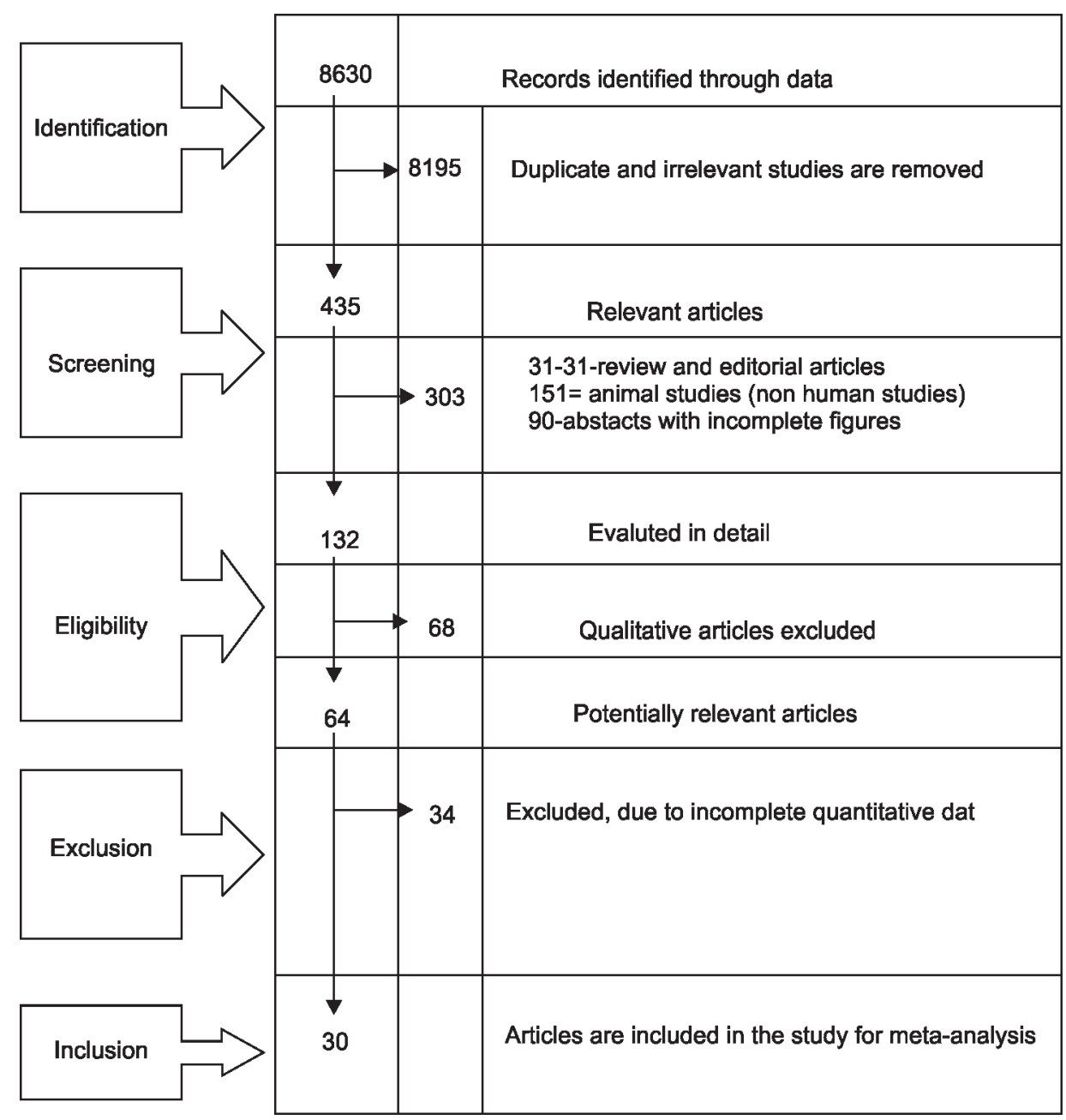

Fig. 1: Selection of studies for meta-analysis of serum homocysteine levels in SCD. This search was conducted by identifying the articles up to May 31, 2018

cell disease" was undertaken in accordance with the Preferred Reporting Items for Systematic reviews and Meta-analysis (PRISM) statement for the systematic reviews of interventional studies were followed. ${ }^{8}$ The three stages comprehensive search of the literature was conducted in the following databases; BioMed Central, Amsterdam. Pub Med ${ }^{\circledast}$ (U.S. National Library of Medicine, USA), www.Blood Journal.org, PLoS ONE.org, ISI Web of Science, Chemical abstract services-(CAS), Europe PMC, Biosis Previews, Elsevier Properties S.A., USA. The studies published before May 31, 2018 , are to be considered and included in meta-analysis.

In the first stage, the necessary databases were searched by using the different concerned search criteria. The Pub Med ${ }^{\circledR}$ database was searched by using the $\mathrm{MeSH}^{\circledR}$ (Medical Subject Headings) term "Sickle Cell Disease" and the keywords "Serum homocysteine level", The Web of Science ${ }^{\circledR}$ databases were searched by using the terms "Sickle Cell Disease" "homocysteine level". The PLoS ONE ${ }^{\circledR}$ database was searched by simply typing the title name on the Google internet. The blood journals were searched simply by typing the name of the journals, and then the title name of the research topic on the internet. In the above-mentioned journals, published results were very limited to human studies, information/ results obtained from books, editorials, commentaries, and conference proceedings were excluded from the studies.

In the second stage, the ideas obtained for reaching the databases using the above research criteria were screened by reading the article "TITLE" and "ABSTRACTS". Studies that were not related to the topic or not satisfying the inclusion criteria were excluded. The third stage is meant for the manuscript screening, and manually searching the data and references for addition. In this stage, articles not satisfying the inclusion criteria were excluded. We excluded literature reviews, cross-sectional studies, studies on animals, articles with missing data, and excluded the qualitative estimated values of serum homocysteine levels in SCD. These inclusion and exclusion search procedures were conducted independently by the reviewer and the final appropriate group of articles was included in the study.

\section{Data Extraction and Analysis \\ Data Extraction}

Data extraction was done independently by two authors, using a standardized data extraction form. To resolve the discrepancies, a statistician was consulted and the information of the variations 
of serum homocysteine level in SCD, based on title, authors, publication year, and name of the study was extracted.

\section{Statistical Analysis}

Thirty studies were included in the statistical analysis which was carried out manually in case of processed variables, partly calculations were carried out by using the latest SPSS-24 software version and Microsoft excel. The Student's independent samples " $t$ " test was done. The statistical graphs had been represented by using the Microsoft Excel software. " $p$ " value of $<0.05$ was considered to be statistically significant.

\section{Results}

Thirty case-control studies were identified, in which 1,272 cases and 1,557 controls. Thirty studies having the comparison of serum homocysteine levels between cases and healthy controls of various SCDs were randomly selected for the analysis. The selection and screenings procedures of the articles are shown in the given Figure 1 and finally the included articles for the meta-analysis is shown in Table 1.

The independent samples " $t$ " test, pooled standard deviation, standard errors, and degree of freedom were calculated by the latest SPSS-24 software version, and calculations were checked and confirmed manually.

The statistical analysis was carried out by considering arithmetic mean and standard deviation of both cases of SCD and healthy controls of individual studies (shown in Table 1).
The pooled or combined standard deviation was 3.59 (SD) for cases and controls and thereafter calculated standard error was found to be $\mathrm{SE}=0.1356$, degree of freedom is $\mathrm{DF}=2,829$, standard mean deviation (SMD) was +3.4 , calculated " $t$ " was 25.07 and $p=0.00000000 \ldots$ is extremely significant (Table 2 ). All the calculations of each and every study with the combined estimation are shown in Table 3.

The individual linear graph is prepared with means and confidence intervals, and for the standard mean difference, a forest plot is prepared for individual studies and combined estimates.

In this meta-analysis, 22 articles showed mean serum homocysteine level in cases is more than that in controls, and the remaining 8 articles showed the opposite result (i.e., level in controls is more than that in cases). Out of 18 articles with sample sizes of both cases and controls more than or equal to 30 subjects, 12 were statistically significant in and remaining 12 articles in which either case or controls sample size is $<30$ subjects, only 6 articles were statistically significant. But it cannot be generalized statistically. ( $p=0.4582$, by Fisher's exact probability test.)

The $2 \times 2$ table was constructed as per sample sizes of both cases and controls more than or equal to 30 samples and anyone $<30$ with statistically significant level was drawn and analyzed by Chi-square test with Yet's correction and Fisher's exact probability test. This can be represented as in the flow diagrams and (Fig. 2).

Table 1: Selected studies for meta-analysis of serum homocysteine in sickle cell disease

\begin{tabular}{|c|c|c|c|c|c|c|c|}
\hline \multirow[b]{2}{*}{ S. no. } & \multirow[b]{2}{*}{ Author, year } & \multicolumn{2}{|c|}{ Sr. (tHcy) sickle cell disease cases } & \multirow{2}{*}{$\begin{array}{l}\text { Sample size } \\
\text { (N) }\end{array}$} & \multicolumn{2}{|c|}{ Healthy control } & \multirow{2}{*}{$\begin{array}{l}\text { Methods and significance } \\
\text { of the study }\end{array}$} \\
\hline & & Mean $\mu \mathrm{mol} / \mathrm{L}$ & $\pm S . D . \mu \mathrm{mol} / \mathrm{L}$ & & Mean $\mu \mathrm{mol} / \mathrm{L}$ & \pm S.D. $\mu \mathrm{mol} / \mathrm{L}$ & \\
\hline 1 & Houston et al., 1997 & 13.3 & 4.3 & $100+100$ & 9.7 & 3.5 & $p<0.02$ ELIZA \\
\hline 2 & van der Dijs et al., 1998 & 12.7 & 4.5 & $19+20$ & 10.9 & 3.5 & ELIZA $p<0.04$ \\
\hline 3 & Schnog et al., 1998 & 5.8 & 2.5 & $34+73$ & 6.1 & 2.7 & Slightly decrease \\
\hline 4 & $\begin{array}{l}\text { Houston et al., } 1997 \\
\text { (stroke) }\end{array}$ & 13.3 & 4.3 & $16+16$ & 9.7 & 3.5 & ELISA $p<0.026$ \\
\hline 5 & Abdelsalam, 2016 & 6.47 & 2.08 & $200+200$ & 4.92 & 1.77 & ELISA, $p<0.069$ \\
\hline 6 & $\begin{array}{l}\text { Vonder Jagt et al., } \\
\text { 2002-(F) }\end{array}$ & 9.47 & 3.3 & $40+37$ & 10.1 & 8.4 & $p=\mathrm{NS}$ \\
\hline 7 & $\begin{array}{l}\text { Vonder Jagt et al., } \\
\text { 2002-(M) }\end{array}$ & 9.6 & 3.4 & $37+40$ & 9.7 & 2.9 & $p=\mathrm{NS}$ \\
\hline 8 & $\begin{array}{l}\text { Olaniyi et al., 2014. Hbs } \\
\text { (voc) }\end{array}$ & 6.34 & 0.72 & $30+30$ & 9.13 & 0.75 & $(\mathrm{HPLC}) p<0.000$ \\
\hline 9 & Olaniyi et al., 2014. Hbss & 5.24 & 0.59 & $30+30$ & 9.13 & 0.75 & $(\mathrm{HPLC}) p<0.000$ \\
\hline 10 & $\begin{array}{l}\text { Al-Nuzaily }{ }^{1} \text { Ali } 2014 \\
\text { (HbAS + SS) }\end{array}$ & 17.4 & 6.8 & $20+20$ & 8.9 & 1.8 & $\begin{array}{l}\text { Enzyme immune assay- } \\
\text { method (EIA) } p<0.001\end{array}$ \\
\hline 11 & $\begin{array}{l}\text { Al-Nuzaily', Ali² } 2014 \\
\text { (Hb-AS) }\end{array}$ & 16.2 & 6.6 & $15+20$ & 8.9 & 1.8 & $\begin{array}{l}\text { Enzyme immune assay- } \\
\text { method (EIA) } p<0.001\end{array}$ \\
\hline 12 & $\begin{array}{l}\text { Al-Nuzaily', Ali } 2014 \\
\text { (Hb-SS) }\end{array}$ & 20.8 & 6.9 & $05+20$ & 8.9 & 1.8 & $\begin{array}{l}\text { Enzyme immune assay- } \\
\text { method (EIA) } p<0.001\end{array}$ \\
\hline 13 & $\begin{array}{l}\text { Johnkennedy et al., } \\
\text { 2015. (Hb-SS) }\end{array}$ & 24.22 & 6.2 & $100+100$ & 13.64 & 4.8 & $\begin{array}{l}\text { Enzymatic colorimetric } \\
\text { method and elevated. } \\
p<0.006\end{array}$ \\
\hline 14 & $\begin{array}{l}\text { Johnkennedy et al., } \\
\text { 2015. (Hb-SS crisis) }\end{array}$ & 27.96 & 6.58 & $30+100$ & 13.64 & 4.8 & $\begin{array}{l}\text { Enzymatic method and } \\
\text { elevated. } p<0.001\end{array}$ \\
\hline 15 & $\begin{array}{l}\text { Vilas-Boas et al., } 2015 \\
\text { (Lower-ACS) }\end{array}$ & 5.8 & 2.61 & $62+143$ & 7.3 & 3.3 & $\begin{array}{l}\text { Enzymatic immunoassay } \\
p<0.021\end{array}$ \\
\hline
\end{tabular}




\begin{tabular}{|c|c|c|c|c|c|c|c|}
\hline \multirow[b]{2}{*}{ S. no. } & \multirow[b]{2}{*}{ Author, year } & \multicolumn{2}{|c|}{ Sr. (tHcy) sickle cell disease cases } & \multirow{2}{*}{$\begin{array}{l}\text { Sample size } \\
\text { (N) }\end{array}$} & \multicolumn{2}{|c|}{ Healthy control } & \multirow{2}{*}{$\begin{array}{l}\text { Methods and significance } \\
\text { of the study }\end{array}$} \\
\hline & & Mean $\mu \mathrm{mol} / \mathrm{L}$ & \pm S.D. $\mu \mathrm{mol} / \mathrm{L}$ & & Mean $\mu \mathrm{mol} / \mathrm{L}$ & $\pm S . D . \mu \mathrm{mol} / \mathrm{L}$ & \\
\hline 16 & $\begin{array}{l}\text { Vilas-Boas et al., } 2015 \\
\text { (Median-ACS) }\end{array}$ & 12.0 & 5.4 & $62+32$ & 7.3 & 3.3 & Enzymatic immunoassay \\
\hline 17 & $\begin{array}{l}\text { Vilas-Boas et al., } 2015 \\
\text { (High-ACS) }\end{array}$ & 14.0 & 6.3 & $62+13$ & 7.3 & 3.3 & $\begin{array}{l}\text { Enzymatic immunoassay } \\
p<0.047\end{array}$ \\
\hline 18 & Pandey et al., 2012 & 25.7 & 8.24 & $40+60$ & 8.7 & 4.25 & ELISA, $p<0.0001$ \\
\hline 19 & Dhar et al., 2004 & 16.09 & 5.87 & $18+2$ & 8.5 & 3.1 & ELISA \\
\hline 20 & Dhar et al., 2004. & 9.7 & 4.2 & $90+76$ & 8.5 & 3.1 & ELISA, $p<0.03$ \\
\hline 21 & $\begin{array}{l}\text { Dhar et al., } 2004 . \\
\text { (Men-5) }\end{array}$ & 18.9 & 6.9 & $5+2$ & 8.5 & 3.1 & ELISA, $p<0.0005$ \\
\hline 22 & $\begin{array}{l}\text { Dhar et al., } 2004 . \\
\text { (women-13) }\end{array}$ & 15.05 & 5.48 & $13+2$ & 8.5 & 3.1 & ELISA, $p<0.0005$ \\
\hline 23 & $\begin{array}{l}\text { Houston et al., } 1997 . \\
\text { (mild SCD stroke) }\end{array}$ & 13.1 & 4.3 & $44+44$ & 9.7 & 3.5 & $p<0.02$ \\
\hline 24 & $\begin{array}{l}\text { Houston et al., } 1997 . \\
\text { (without stroke) }\end{array}$ & 10.7 & 9.7 & $40+40$ & 9.7 & 3.5 & ELISA $p<0.02$ \\
\hline 25 & $\begin{array}{l}\text { Rodriguez-Cortes et } \\
\text { al., 1999. (with acute } \\
\text { complains) }\end{array}$ & 6.1 & 2.7 & $18+18$ & 5.8 & 2.5 & ELISA \\
\hline 26 & $\begin{array}{l}\text { Balasa et al., } 1999 . \\
\text { (stroke in children with } \\
\text { SCD) }\end{array}$ & 5.8 & 2.55 & $40+197$ & 5.4 & 2.32 & $p>0.05$ \\
\hline 27 & $\begin{array}{l}\text { Balasa et al., } 1999 . \\
\text { (stroke in children with } \\
\text { SCD) }\end{array}$ & 6.0 & 2.64 & 40 & 4.8 & 2.06 & $p<0.004$ \\
\hline 28 & Ajayi et al., 2013. & 8.4 & 3.7 & $26+53$ & 9.2 & 3.96 & $\begin{array}{l}\text { Enzymatic method } \\
p=0.4\end{array}$ \\
\hline 29 & Ajayi et al., 2013. Hb-SS & 15 & 6.6 & $4+4$ & 9.2 & 3.96 & Enzymatic method \\
\hline 30 & Ozdem et al., 2007. & 6.44 & 0.44 & $32+27$ & 8.71 & 0.57 & ELISA \\
\hline
\end{tabular}

Table 2: Quantitative analysis of " $t$ " value (DF) and significance levels of 30 studies

\begin{tabular}{rlccl}
\hline S. no. & Study & "t" value & Degree of freedom (DF) & Significance level \\
\hline 1 & Houston et al., 1997 & 6.55 & 198 & $p<0.0000017$ (HS) \\
2 & van der Dijs et al., 1998 & 1.4 & 37 & $p=0.1616$ (NS) \\
3 & Schnog et al., 1998 & 0.55 & 105 & $p=0.5824$ (NS) \\
4 & Houston et al., 1997 (stroke) & 2.59 & 30 & $p<0.0096$ (S) \\
5 & Abdelsalam, 2016 & 8.16 & 398 & $p=0.00000 \ldots$ (HS) \\
6 & Vonder Jagt et al., 2002-(F) & 0.44 & 75 & $p=0.9$ (NS) \\
7 & Vonder Jagt et al., 2002-(M) & 0.14 & 75 & $p<0.00000 \ldots$ (HS) \\
8 & Olaniyi et al., 2014. Hbs (voc) & 14.68 & $5<0.00000 \ldots$ (HS) \\
9 & Olaniyi et al., 2014. Hbss & 22.88 & 58 & $p<0.00000 \ldots$ (HS) \\
10 & Al-Nuzaily, Ali 2014 (HbAS + SS) & 5.41 & 38 & $p<0.0000017$ (HS) \\
11 & Al-Nuzaily, Ali 2014 (Hb-AS) & 4.74 & 33 & $p<0.00000 \ldots$ (HS) \\
12 & Al-Nuzaily, Ali 2014 (Hb-SS) & 7.17 & 23 & $p<00000 \ldots$ (HS) \\
13 & Johnkennedy et al., 2015 (Hb-SS) & 13.15 & 198 & $p<00000 \ldots$ (HS) \\
14 & Johnkennedy et al., 2015 (Hb-SS cris) & 13.14 & 128 & $p<0.0014$ (S) \\
15 & Vilas-Boas et al., 2015 (Lower-ACS) & 3.19 & 203 & $p<0.0000068$ (HS) \\
16 & Vilas-Boas et al., 2015. (Medi.-ACS) & 4.52 & 92 & $p<0.0002$ (S) \\
17 & Vilas-Boas et al., 2015 (High-ACS) & 3.72 & 73 & $p<0.000000 \ldots$ (HS) \\
18 & Pandey et al., 2012 & 13.49 & 98 & $p=0.08$ (NS) \\
19 & Dhar et al., 2004 & 1.77 & 18 & $p=0.04$ (NS) \\
20 & Dhar et al., 2004 & 2.07 & 164 & \\
\hline
\end{tabular}


Contd...

\begin{tabular}{llccl}
\hline S. no. & Study & " $t$ " value & Degree of freedom (DF) & Significance level \\
\hline 21 & Dhar et al., 2004. (Men-5) & 1.97 & 05 & $p=0.1059$ (NS) \\
22 & Dhar et al., 2004 (women-13) & 1.61 & 16 & $p=0.1074$ (NS) \\
23 & Houston et al. 1997 (mild SCD stroke) & 4.05 & 86 & $p<0.00006 \ldots$ (HS) \\
24 & Houston et al., 1997 (without stroke) & 0.61 & 78 & $p=0.54$ (NS) \\
25 & Rodriguez-Cortes et al., 1999 (with acute complains) & 0.34 & 34 & $p=0.74$ (NS) \\
26 & Balasa et al., 1999 (stroke in children with SCD) & 0.98 & 235 & $p=0.33$ (NS) \\
27 & Balasa et al., 1999 (stroke in children with SCD) & 2.26 & 78 & $p=0.0238$ (NS) \\
28 & Ajayi et al., 2013 & 0.86 & 77 & $p=0.39$ (NS) \\
29 & Ajayi et al., 2013 (Hb-SS) & 1.51 & 06 & $p=0.13$ (NS) \\
30 & Ozdem et al., 2007 & 17.46 & 57 & $p<0.00000 \ldots$ (HS) \\
31 & Combined estimation & 25.07 & 2,829 & $p<0.00000 \ldots$ (HS) \\
\hline
\end{tabular}

DF, degree of freedom; $S$, significance; $H S$, highly significance; NS, not significance; SCD, sickle cell disease

Table 3: Showing standard-mean-deviation, LCL-UCL, and weighted mean of 30 articles

\begin{tabular}{|c|c|c|c|}
\hline S. no. & Author and year & $S M D 95 \% C l=(L C L-U C L)$ & Weighted average in $\%$ \\
\hline 1 & Houston et al., 1997 & $+3.6 ; 95 \% \mathrm{Cl}=(2.52$ to 4.68$)$ & $200(7.06)$ \\
\hline 2 & van der Dijs et al., 1998 & $+1.8 ; 95 \% \mathrm{Cl}=(-0.82$ to +4.42$)$ & $39(1.38)$ \\
\hline 3 & Schnog et al., 1998 & $-0.3 ; 95 \% \mathrm{Cl}=(-1.39$ to +0.79$)$ & $107(3.8)$ \\
\hline 4 & Houston et al., 1997 (stroke) & $+3.6 ; 95 \% \mathrm{Cl}=(0.76$ to 6.44$)$ & $32(1.13)$ \\
\hline 5 & Abdelsalam, 2016. & $+1.55 ; 95 \% \mathrm{Cl}=(1.18$ to 1.92$)$ & $400(14.13)$ \\
\hline 6 & Vonder Jagt et al., 2002-(F) & $-0.63 ; 95 \% \mathrm{Cl}=(-3.49$ to +2.23$)$ & $77(2.72)$ \\
\hline 7 & Vonder Jagt et al., 2002-(M) & $-0.1 ; 95 \% \mathrm{Cl}=(-1.54$ to +1.34$)$ & $77(2.72)$ \\
\hline 8 & Olaniyi et al., 2014 Hbs (voc) & $-2.79 ; 95 \% \mathrm{Cl}=(-3.17$ to -2.41$)$ & $60(2.12)$ \\
\hline 9 & Olaniyi et al., 2014. Hbss & $-3.89 ; 95 \% \mathrm{Cl}=(-4.23$ to -3.55$)$ & $60(2.12)$ \\
\hline 10 & Al-Nuzaily Ali 2014 (HbAS + SS) & $+8.5 ; 95 \% \mathrm{Cl}=(+5.33$ to +11.67$)$ & $40(1.41)$ \\
\hline 11 & Al-Nuzaily ${ }^{1}$, Ali $^{2} 2014$ (Hb-AS) & $+7.3 ; 95 \% \mathrm{Cl}=(+4.17$ to +10.43$)$ & $35(1.24)$ \\
\hline 12 & Al-Nuzaily ${ }^{1}$, Ali $^{2} 2014$ (Hb-SS) & $+11.9 ; 95 \% \mathrm{Cl}=(+8.48$ to +15.32$)$ & $25(0.88)$ \\
\hline 13 & Johnkennedy et al., 2015 (Hb-SS) & $+10.58 ; 95 \% \mathrm{Cl}=(+9.04$ to +12.12$)$ & $200(7.06)$ \\
\hline 14 & Johnkennedy et al., 2015 (Hb-SS cris) & $+14.32 ; 95 \% \mathrm{Cl}=(+12.16$ to +16.48$)$ & $130(4.59)$ \\
\hline 15 & Vilas-Boas et al., 2015 (Lower-ACS) & $-1.5 ; 95 \% \mathrm{Cl}=(-2.43$ to -0.57$)$ & $205(7.24)$ \\
\hline 16 & Vilas-Boas et al., 2015 (Median-ACS) & $+4.7 ; 95 \% \mathrm{Cl}=(+2.63$ to +6.77$)$ & $94(3.32)$ \\
\hline 17 & Vilas-Boas et al., 2015 (High-ACS) & $+6.7 ; 95 \% \mathrm{Cl}=(+3.1$ to +10.3$)$ & 75 ( 2.65$)$ \\
\hline 18 & Pandey et al., 2012 & $+17 ; 95 \% \mathrm{Cl}=(+14.51$ to +19.49$)$ & $100(3.53)$ \\
\hline 19 & Dhar et al., 2004 & $+7.59 ; 95 \% \mathrm{Cl}=(-1.42$ to +16.6$)$ & $20(0.71)$ \\
\hline 20 & Dhar et al., 2004 & $+1.2 ; 95 \% \mathrm{Cl}=(+0.06$ to +2.34$)$ & $166(5.86)$ \\
\hline 21 & Dhar et al., 2004 (men-5) & $+10.4 ; 95 \% \mathrm{Cl}=(-3.2$ to +24$)$ & $07(0.25)$ \\
\hline 22 & Dhar et al., 2004 (women-13) & $+6.55 ; 95 \% \mathrm{Cl}=(-2.22$ to +15.32$)$ & $15(0.53)$ \\
\hline 23 & Houston et al., 1997 (mild SCD stroke) & $+3.4 ; 95 \% \mathrm{Cl}=(+1.73$ to +5.07$)$ & $88(3.11)$ \\
\hline 24 & Houston et al., 1997 (without stroke) & $+1 ; 95 \% \mathrm{Cl}=(-2.24$ to +4.24$)$ & $80(2.83)$ \\
\hline 25 & Rodriguez-Cortes et al., 1999 (with acute complains) & $+0.3 ; 95 \% \mathrm{Cl}=(-1.47$ to +2.07$)$ & $36(1.27)$ \\
\hline 26 & Balasa et al., 1999 (stroke in children with SCD) & $+0.4 ; 95 \% \mathrm{Cl}=(-0.41$ to +1.21$)$ & $237(8.37)$ \\
\hline 27 & Balasa et al., 1999 (stroke in children with SCD) & $+1.2 ; 95 \% \mathrm{Cl}=(+0.14$ to +2.26$)$ & $80(2.83)$ \\
\hline 28 & Ajayi et al., 2013 & $-0.8 ; 95 \% \mathrm{Cl}=(-2.66$ to +1.06$)$ & $79(2.79)$ \\
\hline 29 & Ajayi et al., 2013 Hb-SS & $+5.8 ; 95 \% \mathrm{Cl}=(-3.63$ to +15.23$)$ & $08(0.28)$ \\
\hline 30 & Ozdem et al., 2007 & $-2.27 ; 95 \% \mathrm{Cl}=(-2.53$ to -2.01$)$ & $59(2.08)$ \\
\hline 31 & Combined estimation & $+3.4 ; 95 \% \mathrm{Cl}=(+3.13$ to 3.67$)$ & $(100 \%)$ \\
\hline
\end{tabular}

SMD, standard mean deviation; $\mathrm{Cl}$, confidence interval; $\mathrm{LCL}$, lower confidence level; $\mathrm{UCL}$, upper confidence level

*Due to 30 articles, there is a minor variation, however, total matches with 100 


\section{Line Graphs}
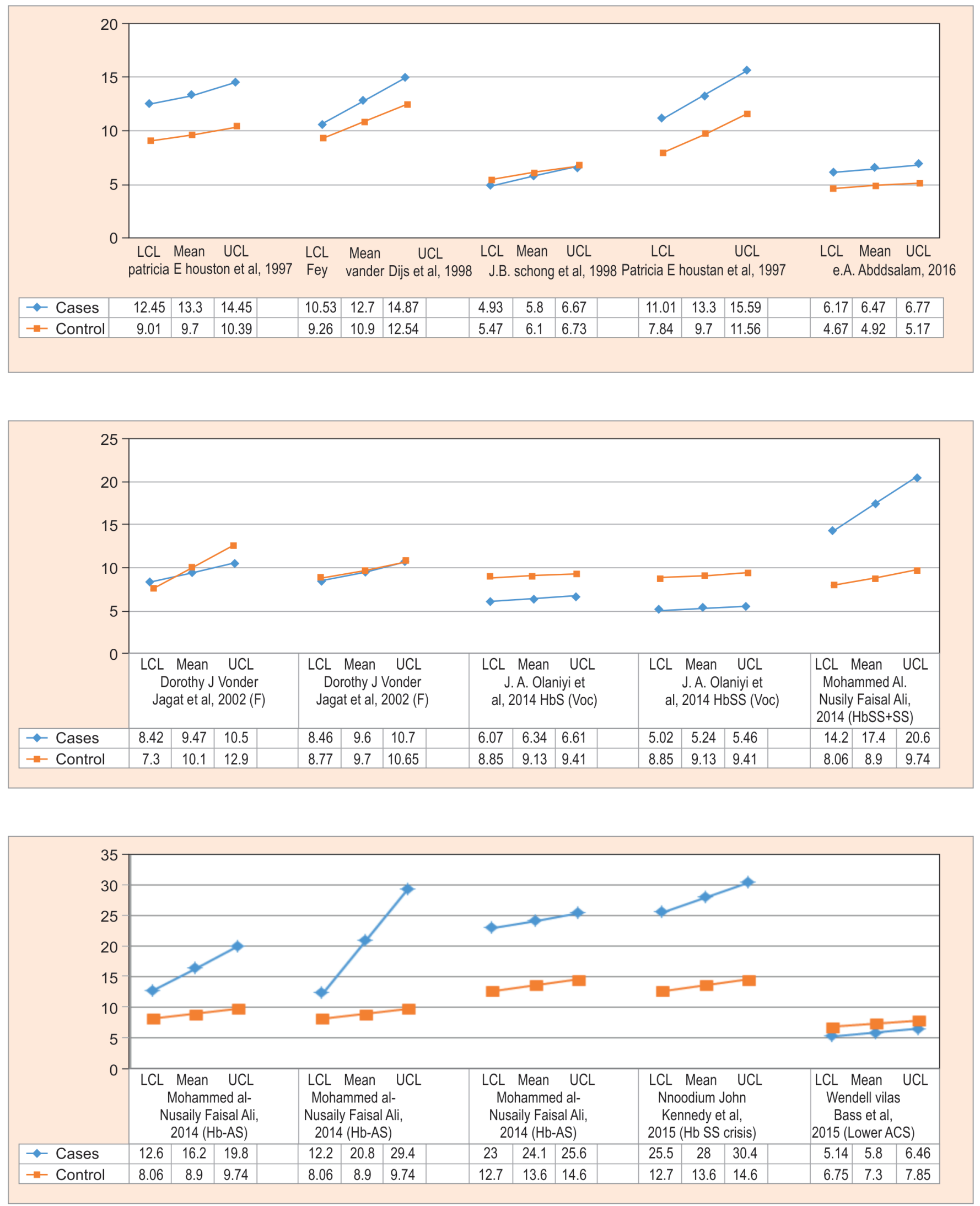
Study of Serum Homocysteine Level Variations in Sickle Cell Disease: A Meta-analysis Study
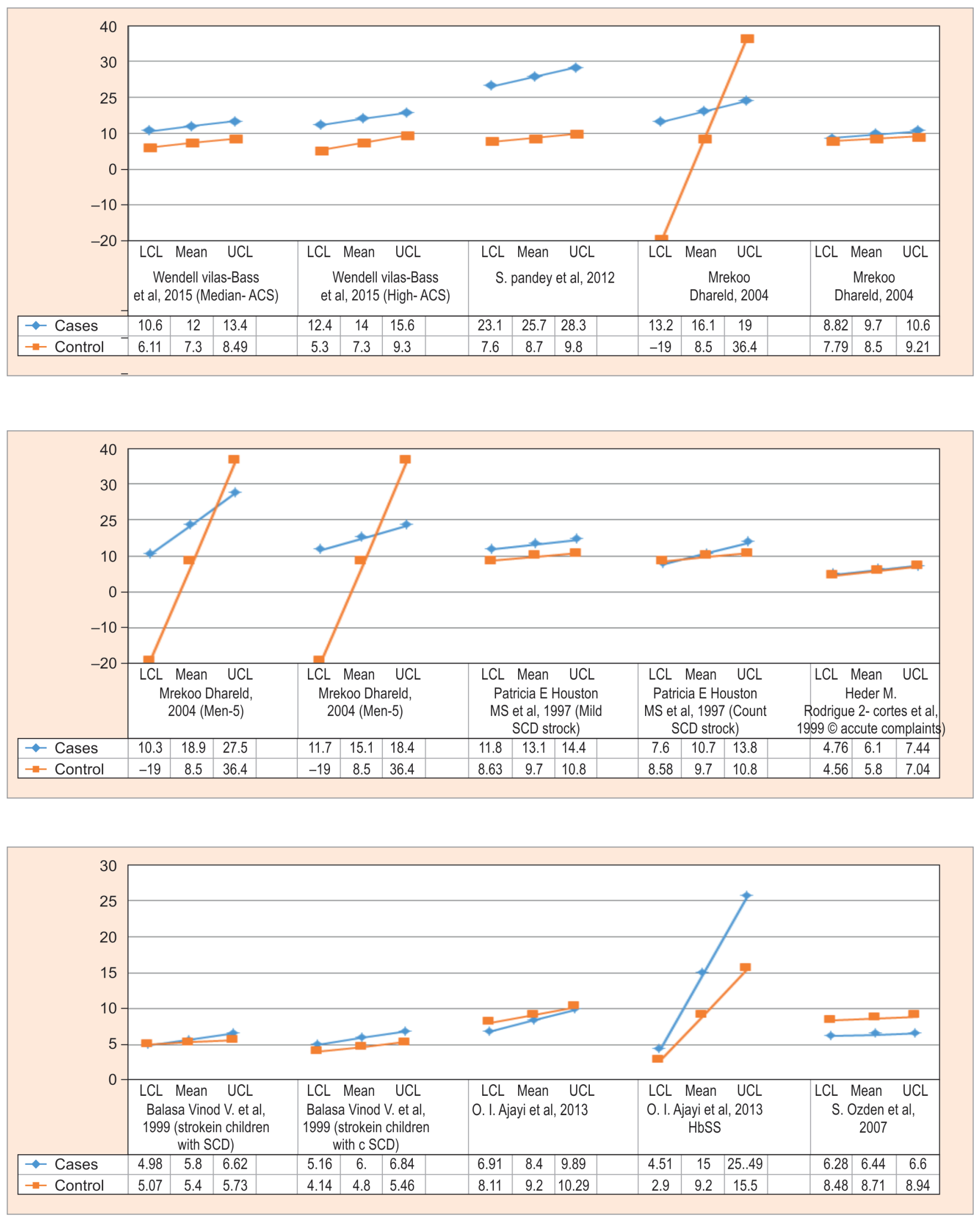


\section{Forestplot}

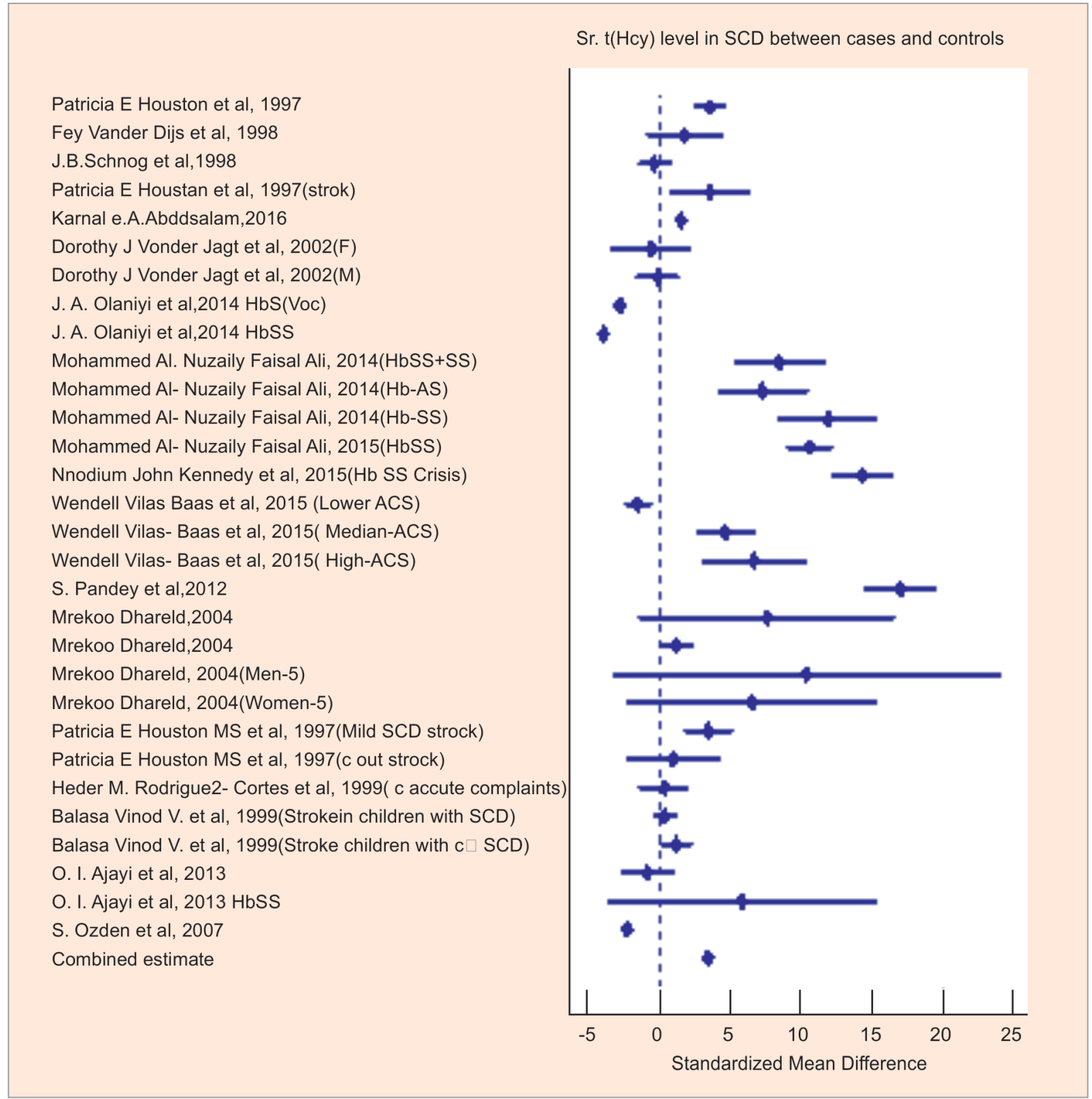

\section{Discussion}

The meta-analysis shows the clinical significance of serum homocysteine in SCD. In this study, 30 articles are incorporated with a total 1,272 number of cases and 1,557 number of controls. The risk factors and pathophysiology of stroke and other serious complications of SCD have not been completely defined. Hyperhomocysteinemia has recently been identified as a risk factor for stroke and other vascular diseases in the general population; however, its role in SCD has not been investigated, so this study is being taken for the meta-analysis.

In this study, Lowenthal et al. and Balasa et al. reported that the serum hyperhomocysteine level was the risk factor for atherosclerosis in SCD patients and Houston et al. reported that the serum homocysteine levels will be high and it may be a risk factor for the development of stroke in SCD patients. ${ }^{6,79}$ In this study, 14 articles/groups are not significant, 3 are significant, and 14 are highly significant.

In non-significant 14 studies, Schnog et al. studied that plasma homocysteine concentrations were measured during acute complications, and observed that, the plasma homocysteine levels in SCA patients and controls were the same. ${ }^{10}$ But in the study of Vonder Jagt et al., male and female, in two different gender studies stated that the mean homocysteine level of male and female was statistically at the higher side (undistinguishable) with the control. ${ }^{11}$ 


\begin{tabular}{|c|c|}
\hline Cases & Controls $=22$ \\
\hline $\begin{array}{l}\text { NN N IIII (14-S) } \\
\text { Significant }\end{array}$ & $\begin{array}{l}\text { NN III } \\
\text { Non Significant }\end{array}$ \\
\hline Cases & Controls $=8$ \\
\hline $\begin{array}{l}\text { III }(03-S) \\
\text { Significant }\end{array}$ & $\begin{array}{l}\mathbb{N}_{(05-\mathrm{NS})} \\
\text { Non Significant }\end{array}$ \\
\hline
\end{tabular}

\begin{tabular}{|c|c|c|c|}
\hline & Significant & Non- Significant & Total \\
\hline Both SS $\geq 30$ & NN $\underset{10.8}{\text { NXN }}$ & $\left.\mathbb{N N}\right|_{7.2} ^{(6)}$ & 18 \\
\hline Any $1 \mathrm{SS}<\mathbf{3 0}$ & $\underset{7.2}{|N|}$ & $\mathbb{N W N}_{4.8}$ & 12 \\
\hline Total & 18 & 12 & 30 \\
\hline
\end{tabular}

Fig. 2: Serum homocysteine status

$X^{2} \mathrm{yc}=0.28, \mathrm{NS}=$ Not significant. $X^{2}=0.83, \mathrm{NS}=$ Not significant

Chi-square without Yet's correction $=0.83$ (Not significant)

Chi-square with Yet's correction $=0.28$ (Not significant) $p=0.4582$

(Fisher's exact probability test) Not significant

But the combined estimate shows positive " $t$ " value 25.07 and $p=0.000000 \ldots$, extremely significant

Dhar et al. (in both sexes), men-5 and women-13, found that the serum homocysteine status in children with SCD was with mixed results. The findings show that mild hyperhomocysteinemia is significantly more common in adult patients with SCD than in control subjects. ${ }^{12-14}$ Houston et al. (without stroke), ${ }^{9}$ RodriguezCortes et al. (with acute complications), and Balasa et al. (stroke in children with SCD) studied and stated that plasma homocysteine levels in the patients with SCA and control subjects were similar and Balasa et al. in 1999 reported that hyperhomocysteinemia is associated with low plasma pyridoxine levels in children with SCD. ${ }^{9,13,14}$

Ajayi et al., Hb-SS., article show that there were no significant differences found between the SCD and controls in MMA or homocysteine but a significantly higher folate concentration was observed in the SCD patients. ${ }^{15}$ The report of Ali et al. clarified that elevation of tHcy is not commonly found in sickle cell trait; but if found elevated, then that may indicate meningeal vessel thrombosis. ${ }^{16}$

In the significant studies, the 4th article, Houston et al. (Stroke) studied that the serum homocysteine levels in the stroke group were significantly higher than those in patients without stroke, and the high levels may be a risk factor for the development of stroke in SCD patients. ${ }^{9}$ In the 15th and 17th articles, Vilas-Boas et al. (lower-ACS), the serum tHcy among SCA subjects was 1.5-fold higher than that of the controls. And, SCD patients have higher plasma concentrations of tHcy despite higher plasma folate levels and vitamin B12 concentrations compared with those observed in healthy individuals. ${ }^{17}$

In the highly significant studies-in the article, Abdelsalam, it was reported that tHcy level was found to be insignificantly higher in patients with sickle cell trait when compared to the control group. ${ }^{18}$ In thromboembolism and cardiovascular disease, the total homocysteine level was increased in $40 \%$ of patients with sickle cell anemia. There was a significant increased mean tHcy level in sickle cell patients by $95 \%$ compared to the control group. ${ }^{19-21}$

In the article Johnkennedy et al., $\mathrm{Hb}-\mathrm{SS}$ and $\mathrm{Hb}$-SS crisis study, the mean level of sr. tHcy was significantly increased in sickle cell anemia $(p<0.05)$, as compared to the control ( $\mathrm{HbAA})$. And the mean level of sr. tHcy was significantly higher in sickle cell crisis than the sickle cell anemia. The result concluded that sickle cell anemia is linked with a rise in sr. homocysteine level, which could lead to increased risk of thromboembolic and cardiovascular disease in sickle cell anemia. ${ }^{22}$ In the article, Vilas-Boas et al. (Medi.ACS), sr. tHcy among SCA subjects was 1.5 -fold higher than that of controls. ${ }^{17}$ Pandey et al. studied 40 sickle cell anemia patients the plasma homocysteine level in sickle cell anemia patients surprisingly elevated. ${ }^{22}$ Houston et al. (mild SCD stroke) reported that the serum homocysteine levels for the stroke group were 
significantly higher than those in patients without stroke, high homocysteine levels may be a risk factor for the development of stroke in SCD patients. ${ }^{9}$ Ozdem et al. reported that the serum homocysteine levels were significantly increased in subjects of SCD. ${ }^{23}$ Balasa et al. stated that the elevated plasma homocysteine (Hcy) is associated with vascular disease and thrombosis in the general population and is believed to induce endothelial cell dysfunction and activate the coagulation system. Patients with SCD exhibit activation. ${ }^{24}$

Pandey et al. stated that the increased homocysteine level was found in Indian sickle cell anemia patients. ${ }^{25}$

In the article Dhar et al. 2004 stated that the plasma total homocysteine (tHcy) was significantly higher in the SCD subjects than the controls. ${ }^{26}$

Lastly, in the pooled estimation of the overall studies is also showing the serum homocysteine level is statistically very highly significant in the subject of SCD. $6,7,9,11,20-26$

\section{CONCLUSION}

The meta-analysis study showed that, out of 30 studies, 22 studies showed that serum homocysteine levels in SCD cases are more than controls, out of 14 articles showed significant differences. Eight studies showed that the serum homocysteine level in SCD cases is less than the healthy controls and only three articles were statistically significant. The combined estimate clearly spells out increased serum homocysteine level in SCD as compared to healthy controls which are observed statistically extremely significant. So, the serum homocysteine level will be beneficial as a clinical biomarker for the diagnosis of SCD.

\section{ACKNOWLedgments}

I would like to thank Biochemistry Departmental Staff for timely help and encouragement. I thank the reviewers for their valuable comments and suggestions.

\section{References}

1. Modell B, Darlison M, Birgens $H$, et al. Epidemiology of haemoglobin disorders in Europe: an overview. Scand J Clin Lab Invest 2007;67(1):39_ 69. DOI: $10.1080 / 00365510601046557$.

2. Akinyanju OO. Profile of sickle cell disease in Nigeria. Ann NY Acad Sci 1989;565(1 Sickle Cell D):126-136. DOI: 10.1111/j.1749-6632.1989. tb24159.x. https://www.ncbi.nlm.nih.gov/pubmed/2672962.

3. Ballas SK. The sickle cell painful crisis in adults: phases and objective signs. Hemoglobin 1995;19(6):323-333. DOI: 10.3109/03630269509005824. https://www.ncbi.nlm.nih.gov/ pubmed/8718691.

4. Van der Dijs FPL, Fokkema MR, Brouwer DA, et al. Optimization of folic acid, vitamin B12 and vitamin B6 supplements in pediatric patients with sickle cell disease. Am J Hematol 2002;69:239-246. DOI: https:// onlinelibrary.wiley.com/doi/pdf/10.1002/ajh.10083.

5. Bialecka M, Robowski P, Honczarenko K, et al. Genetic and environmental factors for hyperhomocysteinaemia and its clinical implications in Parkinson's disease. J Neurologia Polska 2009;43:272285. http://europepmc.org/abstract/med/19618311.

6. Lowenthal EA, Mayo MS, Cornwell PE, et al. Homocysteine elevation in sickle cell disease. J Am Coll Nutrit 2000;19(5):608-612. DOI: 10.1080/07315724.2000.10718958. https://www.ncbi.nlm.nih.gov/ pubmed/11022874
7. Balasa VV, Kalinyak KA, Bean JA, et al. Hyperhomocysteinemia is associated with low plasma pyridoxine levels in children with sickle cell disease. J Pediatr Hematol Oncol 2002;24(5):374-379. DOI: 10.1097/00043426-200206000-00010Try link to: Google; Similars in: SciELO Network Articles in Google Scholar by Vinod V. Balasa, M.D.: http://www.ncbi.nlm.nih.gov/pubMed. Links: Medline, CrossRef.

8. Moher D, Liberati A, Tetzlaff J, et al. Preferred reporting items for systematic reviews and meta analysis; the PRISMA statement. BMJ 2009;339(jul21 1):b2535. DOI: 10.1136/bmj.b2535. https://www.bmj. com/content/339/bmj.b2535

9. Houston PE, Rana S, Sekhsaria $S$, et al. Homocysteine in sickle cell disease: relationship to stroke. Am J Med 1997;103((3):192-196. DOI: 10.1016/S0002-9343(97)00129-0. https://www.sciencedirect.com/ journal/the-american-journal-of-medicine.

10. Schnog JB, Van der Dijs FPL, Brouwer DAJ, et al. Comments from the editor-in-chief. J Pediat Hematol/Oncol 2000;22(2):184-185. DOI: 10.1097/00043426-200003000-00022.

11. Vander Jagt DJ, Shores J, Okorodudu A, et al. Hypocholesterolemia in Nigerian children with sickle cell disease. J Trop Pediat 2002;48(3):156161. DOI: 10.1093/tropej/48.3.156. https://academic.oup.com/tropej/ article/48/3/156/1617112.

12. van der Dijs FPL, Schnog JJB, Brouwer DAJ, et al. Elevated homocysteine levels indicate suboptimal folate status in pediatric sickle cell patients. Am J Hematol 1998;59(3):192-198. DOI: 10.1002/ (SICI)1096-8652(199811)59:3<192::AID-AJH3>3.0.CO;2-8.

13. Balasa VV, Gruppo RA, Gartside PS, et al. Correlation of the C677T MTHFR genotype with homocysteine levels in children with sickle cell disease. J Pediatr Hematol Oncol 1999;21(5):397-400. DOI: 10.1097/00043426-199909000-00011.https://www.ncbi.nlm.nih.gov/ pubmed/10524453.

14. Rodriguez-Cortes HM, Griener JC, Hyland K, et al. Plasma homocysteine levels and folate status in children with sickle cell anemia. J Pediatr Hematol Oncol 1999;3(3):219-223. DOI: https:// onlinelibrary.wiley.com/doi/pdf/10.1002/ajh.20073.

15. Ajayi OI, Bwayo-Weaver S, Chirla S, et al. Cobalamin status in sickle cell disease. Int J Lab Hematol 2013;35(1):31-37. DOI: 10.1111/j.1751553X.2012.01457.x. https://www.ncbi.nlm.nih.gov/pmc/articles/ PMC3484229/.

16. Ali Z, Troncoso JC, Fowler DR. Recurrent cerebral venous thrombosis associated with heterozygote methylene tetrahydrofolate reductase C677T mutation and sickle cell trait without homocysteinemia: an autopsy case report and review of literature. Forensic Sci Int 2014;242:e52-e55. DOI: 10.1016/j.forsciint.2014.07.007. https:// europepmc.org/abstract/med/25074331.

17. Vilas-Boas W, Veloso Cerqueira BA, Figueiredo CVB, et al. Association of homocysteine and inflammatory related molecules in sickle cell anemia. Hematology 2016;21(2):126-131. DOI: https://doi.org /10.1179/1607845415Y.0000000048ISSN: 1024-5332 (Print) 16078454.

18. Abdelsalam KEA. Evaluation of cardiac function tests in sudanese adult patients with sickle cell trait. Med J Indones 2016;25(3):151-156. DOI: 10.13181/mji.v25i3.1412. https://pdfs.semanticscholar.org/f7bd/ 0117319de65032a66ea2b08537a67e724a07.pdf.

19. Cattaneo M. Hyperhomocysteinemia and thrombosis. Lipids 2001;36(Suppl.):13-26. DOI: https://onlinelibrary.wiley.com/doi/ abs/10.1007/s11745-001-0677-9.

20. Sadeghian S, Fallahi F, Salarifar M, et al. Homocysteine, vitamin B12 and folate levels in premature coronary artery disease. BMC Cardiovasc Disord 2006;6(1):38. DOI: 10.1186/1471-2261-6-38/ PMID:17002799/PMCID:PMC1592513.

21. Virdis A, Ghiadoni L, Salvetti G, et al. Hyperhomocysteinemia: is a novel risk factor in hypertension? J Nephrol 2002;15:414-421. http:// europepmc.org/abstract/med/12243373. 
22. Johnkennedy N, Uche UB, Chidozie NJ, et al. Alterations of homocysteine in sickle cell anaemia. J Med Biol Sci Re 2015;1(4):44-46. http://oaji.net/articles/2015/2206-1437975476.pdf. ISSN: 2449-1810.

23. Ozdem S, Kupesiz A, Yesilipek A. Plasma homocysteine levels in patients with $\beta$-thalassaemia major. Scandinav J Clin Laborat Investigat 2008;68(2):134-139. DOI: 10.1080/00365510701516343. https://www.ncbi.nlm.nih.gov/pubmed/18382931.

24. Al-Maktari LAS, AI-Nuzaily MAK, Bamashmoos SA, et al. Thrombotic events in patients with sickle cell anemia: relationship to protein C, S and total homocysteine levels. Int J Curr Aca Rev 2014;2(2):17-24.
http://www.ijcrar.com/vol-2-2/Lutfi\%20AS.\%20Al-Maktari,\%20 et\%20al.pdf. ISSN: 2347-3215.

25. Pandey S, Pandey HR, Mishra RM, et al. Increased homocysteine level in Indian sickle cell anemia patients. Ind J Clin Biochem 2012;27(1):103104. DOI: 10.1007/s12291-011-0158-7. https://www.ncbi.nIm.nih.gov/ pmc/articles/PMC3286591/.

26. Dhar M, Bellevue R, Brar S, et al. Mild hyperhomocysteinemia in adult patients with sickle cell disease: a common finding unrelated to folate and cbalamin status. Am J Hematol 2004;76(2):114-120. DOI: https:// onlinelibrary.wiley.com/doi/abs/10.1002/ajh.20073/. 